\title{
Novel Analog of Atrial Natriuretic Peptide Selective for Receptor-A Produces Increased Diuresis and Natriuresis in Rats
}

\author{
Hongkui Jin, Bing Li, Brian Cunningham, Jeffrey Tom, Renhui Yang, Patricia Sehl, G. Roger Thomas, Annie Ko, \\ David Oare, and David G. Lowe \\ Departments of Cardiovascular Research, Protein Engineering and Bioorganic Chemistry, Genentech, Inc., South San Francisco, \\ California 94080
}

\begin{abstract}
Atrial natriuretic peptide (ANP) binds to natriuretic peptide receptor-A (NPR-A), a membrane guanylyl cyclase, and to natriuretic peptide receptor-C (NPR-C), which plays a role in peptide clearance. Rat ANP (rANP) mutants that bind rat NPR-A selectively over rat NPR-C were isolated from randomized libraries of rANP-display phage by differential panning. One variant was identified with reduced NPR-C binding; rANP (G16R, A17E, Q18A) [rANP(REA18)]. Synthetic rANP(REA18) was equipotent with rANP in stimulating cGMP production from cloned rat NPR-A $\left(\mathrm{ED}_{50}=\right.$ $1.8 \mathrm{nM}$ ) and was reduced in NPR-C binding by $\sim 200$-fold. When infused into conscious rats at $0.325 \mu \mathrm{g} / \mathrm{min}$ for 30 min rANP elicited an identical decrease in blood pressure compared with $0.25 \mu \mathrm{g} / \mathrm{min}$ of $\mathrm{rANP}(\mathrm{REA18})$, however the natriuretic $(P<0.05)$ and diuretic $(P=0.07)$ responses to rANP(REA18) were greater. These data are consistent with a role for NPR-C as a local decoy receptor attenuating NPR-A effects in the kidney, where these receptors are coexpressed. Improved NPR-A specificity could provide more effective natriuretic peptides for treatment of acute renal failure or heart failure. (J. Clin. Invest. 1996. 98:969-976.) Key words: atrial natriuretic peptide - phage display • cGMP • natriuresis • diuresis
\end{abstract}

\section{Introduction}

Atrial natriuretic peptide (ANP), ${ }^{1}$ a circulating hormone derived principally from cardiac atrial myocytes, plays a role in the control of salt and water homeostasis and blood pressure (1-3). The effects of ANP on blood pressure and fluid balance are mediated through antagonism of endothelin and vasopressin and the renin-angiotensin-aldosterone system $(1,4)$. In addition, ANP is a vasodilator and also has direct actions on

Address correspondence to David G. Lowe, Cardiovascular Research Department, Genentech, Inc., 460 Pt. San Bruno Blvd., South San Francisco, CA 94080. Phone: 415-225-2738; FAX: 415-225-6327; E-mail: lowe@gene.com

Received for publication 29 November 1995 and accepted in revised form 20 June 1996.

1. Abbreviations used in this paper: ANP, atrial natriuretic peptide; $h$, human; HR, heart rate; MAP, mean arterial pressure; NEP, neutral endopeptidase; NPR, natriuretic peptide receptor; r, rat; rANP(REA18), rANP(G16R, A17E, Q18A).

J. Clin. Invest.

(C) The American Society for Clinical Investigation, Inc.

0021-9738/96/08/0969/08 \$2.00

Volume 98, Number 4, August 1996, 969-976 the kidney including increased glomerular filtration, inhibition of sodium reabsorption, and redistribution of renal blood flow to promote natriuresis and diuresis $(1,4)$.

For several of the responses to ANP, including increased glomerular filtration, natriuresis, and direct vasorelaxation (1, 4-6), there is evidence that cGMP is the intracellular second messenger of hormone action. Two ANP receptors have been cloned and expressed to date. One of the these, natriuretic peptide receptor-A (NPR-A), also known as guanylyl cyclase-A (GC-A), is a membrane enzyme that synthesizes cGMP in response to extracellular ligand binding $(7,8)$. Localization of the mRNA encoding this receptor by Northern blotting and in situ hybridization shows that the most abundant expression is in major target organs for ANP action, including the kidney, adrenal, and pituitary (8-10).

The second ANP receptor, NPR-C, is also a type-I membrane protein homologous to NPR-A in the extracellular domain, but has only a short cytoplasmic region of 37 amino acids (11). NPR-C is thought to principally mediate the metabolic clearance of ANP $(12,13)$. Other work has suggested that NPR-C plays a role in signal transduction (14), but this receptor is apparently not directly involved in the adrenal, renal, or cardiovascular actions of ANP. Expression of NPR-C has been described in a variety of tissues (14) including the kidney glomerulus $(9,15)$, where it is coexpressed with NPR-A. The pattern of NPR-C expression is not identical to NPR-A. The kidney, adrenal, lung, and heart are tissues where both receptors have been identified, but abundant colocalization is only prominent in the kidney glomerulus, whereas the pituitary and vascular smooth muscle apparently express much less NPR-C than NPR-A $(9,10,14)$.

Research on the structure-activity relationships of ANP have focused on improving the molecules pharmacological properties. ANP variants with longer half-life and improved receptor specificity may be clinically useful for the treatment of renal failure, hypertension, and congestive heart failure (1, 4). Only recently, however, have ANP analogs specific for NPR-A, with no binding to NPR-C, been developed (16). Compounds with NPR-A selectivity would be expected to have a decreased metabolic clearance rate and longer half-life resulting in enhanced potency $(17,18)$. There is also the potential for enhanced responsiveness in the kidney, where coexpression of NPR-C and NPR-A may result in an attenuated NPR-A response due to receptor competition for ligand (16). Although this hypothesis is supported by in vitro cell culture data, there is no direct in vivo pharmacological evidence to suggest that NPR-A selectivity will provide an improved renal response. Investigating the in vivo advantages to NPR-A selectivity have been hampered by the species specificity of the currently available analog for the human receptor, which has significantly reduced affinity for rat NPR-A (16).

We describe here the identification of a rat NPR-A selective ANP analog by competitive panning of mutant ANP phage 
display libraries for sequences that bind preferentially to rat NPR-A in the presence of competing rat NPR-C. Analysis of the in vitro and in vivo pharmacology of this novel ANP analog suggests that specific targeting of NPR-A could be an effective clinical strategy for modulating renal function.

\section{Methods}

Receptor expression. Cloning and expression of the rat NPR-C (rNPR-C) cDNA as an extracellular domain-IgG Fc fusion protein (rC-IgG) has been described (19). Full-length rat NPR-C was expressed in human (h) kidney 293 cells as previously described for hNPR-C (16). For rNPR-A (7) the extracellular domain coding region was fused to the $\mathrm{Fc}$ portion of human $\mathrm{IgG}$ to produce the expression construct p.rA-IgG in direct analogy to the human fusion protein (20). For soluble receptor production, stable cell lines were seeded into spinner flasks at $3.5 \times 10^{5}$ cells $/ \mathrm{ml}$ and changed to serum-free media the next day. Medium was conditioned for 3-4 d before collection, adjusted to $0.7 \mathrm{mg} / \mathrm{ml}$ pepstatin $\mathrm{A}, 0.5 \mathrm{mg} / \mathrm{ml}$ leupeptin and 1 $\mathrm{mM}$ PMSF, and sterile-filtered through a $0.22-\mu \mathrm{m}$ membrane (Nalgene Co., Rochester, NY) before storage at $-80^{\circ} \mathrm{C}$.

Sorting of rANP display phage. Previously we have described a hANP phagemid (pB1537) (16) and subsequent modifications (pB1743) (21) that increase the efficiency of ANP display on the surface of the phagemid without affecting binding to hNPR-A. Here we introduced the mutation M12I to produce phagemid (pL0165) that displays rANP and binds to both $\mathrm{rA}-\mathrm{IgG}$ and $\mathrm{rC}$-IgG receptors with high affinity. Rat ANP variants that preferentially bound rNPR-A over rNPR-C were selected from randomized libraries using the differential panning method previously described (16). A total of four libraries that displayed rANP variants having residues randomized to all 20 amino acids at positions 8-11, 12-15, 16-19, and 20-22 were constructed by site-directed mutagenesis using the following oligonucleotides that changed target codons to NNS sequences $(\mathrm{N}=\mathrm{G}, \mathrm{A}, \mathrm{T}$, or $\mathrm{C}$, and $\mathrm{S}=\mathrm{C}$, or $\mathrm{G}$ ): 5'-CTCGATAGATCTAGCTGCNNSNNS NNSNNSATCGATCGTATC-3', 5'-AGCTGCTTGGCGGCCGCN NSNNSNNSNNSGGAGCTCAGAGC-3', 5'-GGCCGCATCGAT CGTATCNNSNNSNNSNNSGGTCTCGGGTGC-3', and 5'-CGT ATCGGAGCTCAGAGCNNSNNSNNSTCAACAGCTTCCG-3' . Each library consisted of $(1-10) \times 10^{7}$ independent mutants and was sufficient to represent all possible sequence combinations. These libraries were each subjected to seven rounds of sorting with solid phase rA-IgG and competing solution phase rC-IgG. Individual clones were analyzed by phage ELISA (16) for binding to immobilized receptors to determine receptor specificity, and sequenced to identify mutations in the ANP sequence.

Synthetic peptides. Rat ANP was purchased from Bachem California (Torrance, CA), and rANP(REA18) was synthesized by solid phase methods using standard tBOC chemistry followed by reverse phase HPLC purification. Dried peptide aliquots were prepared and stored as described (22), and duplicate samples were subjected to quantitative amino acid analysis to measure peptide content.

NEP assays. Kinetic assay conditions were based on those previously reported (23). Peptides in a range of concentrations $(5-250 \mu \mathrm{M})$ in $50 \mathrm{mM}$ Hepes $\mathrm{pH} 7.5$ were prewarmed to $37^{\circ} \mathrm{C}$ in a water bath. $\mathrm{Pu}-$ rified recombinant human neutral endopeptidase (NEP) was then added to the peptide solutions to a final volume of $100 \mu \mathrm{l}$ and incubated at $37^{\circ} \mathrm{C}$ for two different reaction times. The reactions were terminated by the addition of $5 \mu \mathrm{l}$ of $10 \%$ TFA (trifluoroacetic acid)/water $(\mathrm{vol} / \mathrm{vol})$. The amounts of NEP and the time periods used were: rANP, $75 \mathrm{ng}, 12$ and $18 \mathrm{~min}$; rANP(REA18), $18 \mathrm{~min}, 75$ and $150 \mathrm{ng}$. The products of the reactions were monitored by HPLC and the peak areas of the starting peptide were measured by computerized integration. The total extent of hydrolysis of all the peptides ranged from 5 to $65 \%$. Kinetic constants $K_{\mathrm{m}}$ and $V_{\max }$ were obtained from linear transformations of the Michaelis-Menten equation and graphical analysis of Lineweaver-Burk plots of the data using least squares analysis. Values of $\mathrm{K}_{\text {cat }}$ were calculated assuming a mass of $90,000 \mathrm{D}$ for NEP.

Membrane preparation. Stable 293 cell lines expressing rat NPRA(22) or rat NPR-C were removed from cell culture dishes with 0.5 $\mathrm{mM}$ EDTA in PBS, placed in ice-cold PBS and centrifuged at $228 \mathrm{~g}$ for $10 \mathrm{~min}$ at $4^{\circ} \mathrm{C}$. Cell pellets were resuspended in ice-cold homogenization buffer (50 mM Hepes, $1 \mathrm{mM}$ EDTA, $1 \mathrm{mM}$ DTT, $0.25 \mathrm{M}$ sucrose, $0.7 \mathrm{mg} / \mathrm{ml}$ pepstatin $\mathrm{A}, 0.5 \mathrm{mg} / \mathrm{ml}$ leupeptin and $1 \mathrm{mM}$ PMSF, $\mathrm{pH}$ 7.4), homogenized using a polytron (Brinkman Instruments, Inc., Westbury, NY) at setting 5 for $30 \mathrm{~s}$, then centrifuged at $400 \mathrm{~g}$ for $10 \mathrm{~min}$ at $4^{\circ} \mathrm{C}$. The supernatant was collected and centrifuged at $100,000 \mathrm{X} \mathrm{g}$ for $30 \mathrm{~min}$ at $4^{\circ} \mathrm{C}$. The membrane pellet was disrupted using a $7 \mathrm{ml}$ Kontes Dounce tissue grinder (Fisher Scientific, Pittsburgh, PA) in storage buffer ( $50 \mathrm{mM}$ Hepes, $0.1 \mathrm{mM}$ EDTA, $5 \mathrm{mM} \mathrm{MgCl} 2,100 \mathrm{mM}$ $\mathrm{NaCl}, 0.7 \mathrm{mg} / \mathrm{ml}$ pepstatin A, $0.5 \mathrm{mg} / \mathrm{ml}$ leupeptin and $1 \mathrm{mM}$ PMSF, $\mathrm{pH}$ 7.4) and aliquots were frozen on dry ice before storage at $-80^{\circ} \mathrm{C}$. Protein concentration was determined using a protein assay (Bio-Rad Laboratories, Richmond, CA) with IgG as a standard.

Membrane competition binding assays. Membranes diluted in 50 $\mathrm{mM}$ Hepes, $5 \mathrm{mM} \mathrm{MgCl} 2,0.1 \mathrm{M} \mathrm{NaCl}, 0.1 \mathrm{mM}$ EDTA, $0.2 \%$ BSA, pH 7.4 were added to 96-well polypropylene plates (Sigma Chemical Co., St. Louis, $\mathrm{MO}$ ) with an equal volume containing unlabeled competing peptide and $30 \mathrm{pM}{ }^{125} \mathrm{I}$-rANP $(3,000 \mathrm{Ci} / \mathrm{mmol}$, Amersham Corp., Arlington Heights, IL), and incubated for $2 \mathrm{~h}$ at $22^{\circ} \mathrm{C}$. Bound peptide was separated from free by vacuum filtration through $1 \%$ polyethyleneimine-treated Packard unifilter-96 GF/B filter plates using a Packard Filtermate 196 cell harvester (Packard Instrument Co., Meriden, CT). The plates were washed six times with PBS, air dried before adding scintillant and counted in a Packard Topcount scintillation counter for $1 \mathrm{~min} /$ well. Binding was measured in duplicate for each concentration of competitor.

Concentration response of cGMP production. A stable 293 rNPR-A cell line (22) was used to determine natriuretic peptide agonist potencies. Peptide treatments and cGMP radioimmunoassay (Biomedical Technologies, Inc., Stoughton, MA) were carried out essentially as described $(22,24)$. All stimulations were performed in triplicate and samples were measured in duplicate for cGMP.

Data analysis. The competition binding curves and cGMP concentration responses were analyzed by the four-parameter logistic equation with the KaleidaGraph program (Synergy Software, Inc., Reading, PA) to obtain estimates of the $\mathrm{IC}_{50}$ or $\mathrm{EC}_{50}$ values. The nonlinear least-squares curve fitting program LIGAND (25) was used to analyze the competition binding curves.

Animals. Male Sprague-Dawley (SD) rats (8-wk of age; Charles River Breeding Laboratories, Inc., Wilmington, MA) were acclimated to the facility for at least $1 \mathrm{wk}$ before surgery, fed a pelleted rat chow and water ad libitum, and housed in a light and temperature controlled room. The experimental procedures, which were approved by Genentech's Institutional Animal Care and Use Committee, conform to the guiding principles of the American Physiological Society.

Vasorelaxation experiments. Rings of thoracic aorta were prepared from 350-400-gram rats. Each rat was anesthetized with $60 \mathrm{mg} /$ $\mathrm{kg}$ (i.p.) pentobarbital sodium (Abbott Laboratories, North Chicago, IL) and following thoracotomy the aorta was removed and placed in Krebs-Henseleit solution, containing $118 \mathrm{mM} \mathrm{NaCl}, 4.7 \mathrm{mM} \mathrm{KCl}, 2.5$ $\mathrm{mM} \mathrm{CaCl}_{2}, 1.6 \mathrm{mM} \mathrm{MgSO}_{4}, 25 \mathrm{mM} \mathrm{NaHCO}_{3}, 1.2 \mathrm{mM} \mathrm{KH}_{2} \mathrm{PO}_{4}$, and $5.5 \mathrm{mM}$ glucose, and gassed with $95 \% \mathrm{O}_{2} / 5 \% \mathrm{CO}_{2}$. Any associated connective tissue was trimmed and the aorta cut into 2-3 mm-wide rings which were suspended in $15 \mathrm{ml}$ organ baths under 1.5 grams of tension. After 20 min of equilibration, during which the bathing solution was constantly exchanged, the tissue was submaximally preconstricted with phenylephrine $\left(5 \times 10^{-8} \mathrm{M}\right)$. The presence of endothelium was confirmed by vasodilator responses to acetylcholine $(1 \times$ $\left.10^{-6} \mathrm{M}\right)(26)$. Following washout and subsequent preconstriction, cumulative dose-response curves to the vasodilatory effects of either rANP or rANP(REA18) were constructed in each tissue. All responses were measured using Grass FT03 isometric strain gauges coupled to a model 79D Grass polygraph (Grass Instrument Co., 


\section{IANP \\ 1 rANP (REA18) SLRRSSCFGGRIDRIGAQSGLGCNSFRY}

Figure 1. Sequence of rANP and rANP(REA18). The amino acid sequence of the 28 residue rat ANP is shown in signal letter code with the disulfide bond indicated by a line connecting $\mathrm{C} 7$ to $\mathrm{C} 23$. Dashes indicate identical residues for rANP(REA18) compared with rANP.

Quincy, MA). Phenylephrine hydrochloride (Sigma Chemical Co.) was dissolved as $1 \mathrm{mg} / \mathrm{ml}$ stock solution in $0.9 \%$ (wt/vol) saline solution containing $1 \mathrm{mg} / \mathrm{ml}$ sodium ascorbate. $\mathrm{rANP}$ and $\mathrm{rANP}(\mathrm{REA} 18)$ were dissolved as $10 \mu \mathrm{M}$ stock solutions in PBS.

Surgery. Rats were anesthetized by intraperitoneal injection of ketamine $(80 \mathrm{mg} / \mathrm{kg}$ ) (Aveco Co., Inc., Fort Dodge, IA) and xylazine (10 mg/kg); (Rugby Laboratories, Inc., Rockville Center, NY). A catheter (PE-10 fused with PE-50) filled with heparin saline solution $(50 \mathrm{U} / \mathrm{ml})$ was implanted into the abdominal aorta via the right femoral artery for measurement of mean arterial pressure (MAP) and heart rate (HR). A second catheter was inserted into the right femoral vein for intravenous infusions. The catheters were exteriorized and fixed at the back of the neck. To reduce the capacity of the bladder to facilitate the collection of urine, $75 \%$ of the bladder was excised, taking care not to disturb the ureters or urethra (27). Urine was allowed to drain naturally from the penis. After surgery, all rats were housed individually.

Measurements of MAP and HR. $2 \mathrm{~d}$ after surgery, each rat was placed in a restrainer. The arterial catheter was connected to a pressure transducer (CP-10; Century Technology Co., Inglewood, CA) coupled to a polygraph (7; Grass Instruments, Quincy, MA) and MAP and HR were monitored throughout the experiment.

Administration of natriuretic peptides. After a 45-min stabilization period rats received intravenous infusion of saline $(50 \mu \mathrm{l} / \mathrm{min})$ for $30 \mathrm{~min}$ as a control period. rANP $(0.25$ or $0.325 \mu \mathrm{g} / \mathrm{min})$ or rANP(REA18) $(0.25 \mu \mathrm{g} / \mathrm{min})$ in saline was then infused intravenously for $30 \mathrm{~min}$ as an infusion. Finally, the rats were given an intravenous infusion of saline for $30 \mathrm{~min}$ as a recovery period. A pilot study in conscious rats had shown that an intravenous infusion of rANP at a dose of $0.25 \mu \mathrm{g} / \mathrm{min}$ exerted significant depressor and diuretic effects, and that rANP at $0.325 \mu \mathrm{g} / \mathrm{min}$ induced a similar depressor response as compared to $\mathrm{rANP}(\mathrm{REA} 18)$ at $0.25 \mu \mathrm{g} / \mathrm{min}$.

Collection of blood and urine. Urine samples were collected over each $30 \mathrm{~min}$ period. Blood $(0.5 \mathrm{ml})$ was collected through the arterial catheter into iced tubes containing EDTA and aprotinin at the end of the control or infusion period. Plasma was immediately separated by centrifugation at $4^{\circ} \mathrm{C}, 1,500 \mathrm{~g}$ for $20 \mathrm{~min}$. Urine and plasma samples were stored at $-80^{\circ} \mathrm{C}$ until assay.

Urine and plasma cGMP assay. Urine $\mathrm{Na}^{+}$concentrations were assessed by flame photometry. Plasma and urinary cGMP levels were determined by radioimmunoassay (Biomedical Technologies, Inc.).

Statistical analysis. Results were expressed as mean \pm SEM. Oneway ANOVA were performed to assess differences in parameters between groups. Significant differences were then subjected to post-hoc

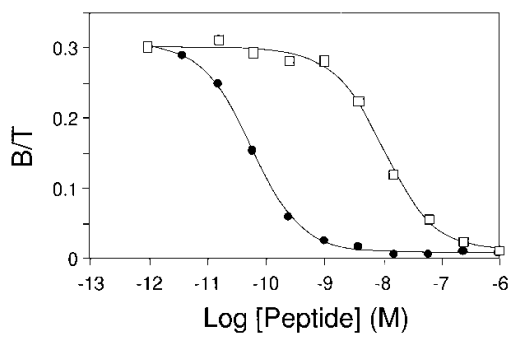

Figure 2. Competition binding on cloned rNPR-C. Competitive binding to membranes from cells expressing recombinant rNPR-C is shown for rANP $(\bullet)$ and $\mathrm{rANP}(\mathrm{REA} 18)$ ( $\square)$. Results are plotted as the ratio of bound/to-

tal $(B / T)^{125} \mathrm{I}$-rANP versus the concentration of competing natriuretic peptide. Values are averages of duplicate measurements.

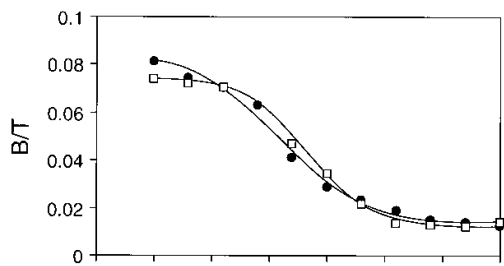

Figure 3. Binding and agonist potency on rNPR-A. Binding to rNPR-A showed one site for $\mathrm{rANP}\left(\mathrm{IC}_{50}=\right.$ $237 \mathrm{pM})(\bullet)$ compared with $\mathrm{AANP}(\mathrm{REA} 18)$ $\left(\mathrm{IC}_{50}=438 \mathrm{nM}\right)(\square)$ (a). Values are

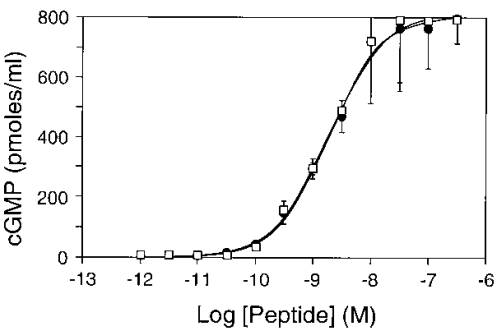
averages of duplicate determinations. Stimulation of cGMP production $(b)$ showed rANP (๑) and rANP(REA18) ( $\square$ ) to be equipotent $\left(\mathrm{ED}_{50}=1.8 \mathrm{nM}\right)$. Values are averages \pm standard deviation $(n=3)$.

analysis using the Newman-Keuls method. $P<0.05$ was considered significant.

\section{Results}

Mutant ANP selective for rat NPR-A. To develop an ANP variant selective for rNPR-A we used the previously described method of differential panning with libraries of mutant ANP display phage in which segments of 3-4 codons in ANP were completely randomized (16). In this work, we found that specificity mutations conferring hNPR-A selectivity occurred only in the 17 amino acid disulfide bonded ring of hANP. Based on this result, we constructed four libraries of mutant rANP display phage that contained random mutations within the ring, and subjected them to seven rounds of differential panning with immobilized $\mathrm{rA}-\mathrm{IgG}$ in competition with solution phase rC-IgG. The best receptor-selective rANP sequence identified contained three mutations, G16R, A17E, and Q18A [designated rANP(REA18)] (Fig. 1). An analysis of binding affinities by phage-ELISA showed that these variant phagemid were $\sim 130$-fold reduced in affinity for rNPR-C yet retained wild-type affinity for rNPR-A.

Synthesis of rANP(REA18) allowed us to confirm that receptor selectivity was retained in the free peptide. Solution equilibrium binding studies were performed with membranes from human embryonic kidney 293 cells that express recombinant rNPR-C or rNPR-A. rANP(REA18) inhibits ${ }^{125}$ I-rANP binding to rNPR-C with an $\mathrm{IC}_{50}=10 \mathrm{nM}$, compared to $\mathrm{IC}_{50}=58$

Table I. Kinetic Constants for NEP Degradation of Peptides

\begin{tabular}{|c|c|c|c|c|c|c|}
\hline Peptide & ng NEP & $\begin{array}{c}\text { Reaction } \\
\text { time }\end{array}$ & $K_{\mathrm{m}}$ & $V_{\max }$ & $\mathrm{k}_{\mathrm{cat}}$ & $\mathrm{k}_{\text {cat }} / K_{\mathrm{m}}$ \\
\hline & & $\min$ & $\mu M$ & $\begin{array}{c}\mu \mathrm{mol} / \mathrm{min} \\
\text { per } \mathrm{mg}\end{array}$ & $\min ^{-1}$ & $\mu M^{-1} \min ^{-1}$ \\
\hline rANP(REA18) & 75 & 18 & 19.5 & 0.4 & 34.0 & 1.7 \\
\hline rANP(REA18) & 75 & 18 & 22.1 & 0.4 & 33.4 & 1.5 \\
\hline rANP(REA18) & 150 & 18 & 30.4 & 0.5 & 42.2 & 1.4 \\
\hline rANP & 75 & 18 & 120.5 & 2.9 & 256.8 & 2.1 \\
\hline rANP & 75 & 12 & 142.2 & 4.3 & 384.6 & 2.7 \\
\hline
\end{tabular}




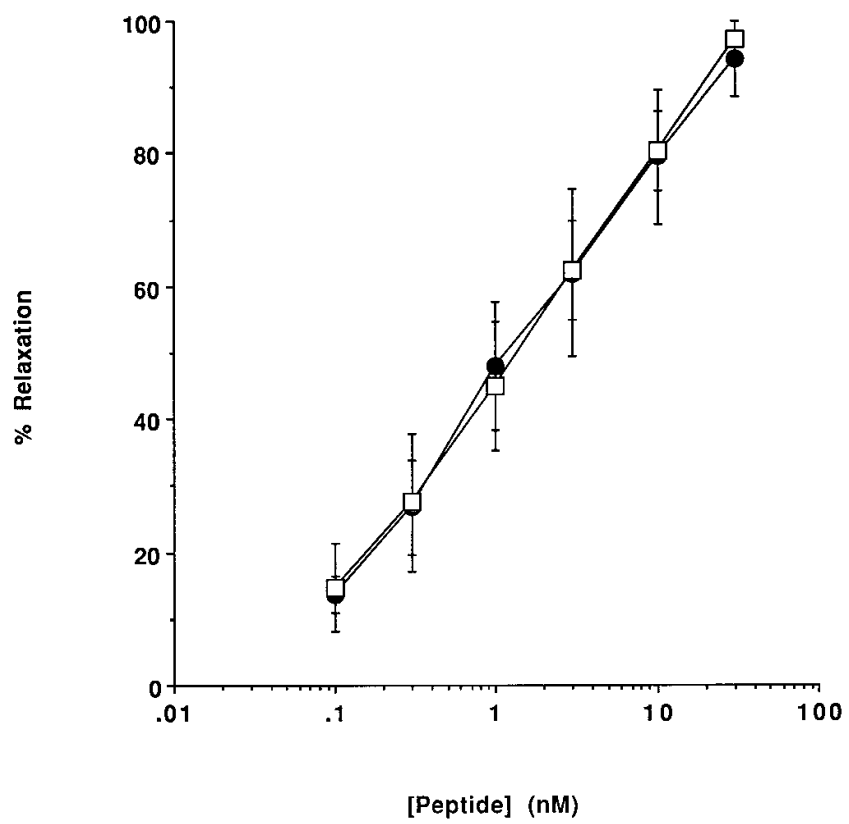

Figure 4. Concentration response for relaxation of phenylephrine contracted aortic rings. Percent relaxation is plotted as a function of peptide concentration $(n M)$ for $\operatorname{rANP}(\bullet)$ and $\operatorname{rANP}(\mathrm{REA} 18)(\square)$. Values are expressed as mean $\pm \operatorname{SEM}(n=4)$.

pM for rANP (Fig. 2). rANP bound to rNPR-A with $\mathrm{IC}_{50}=237$ pM (Fig. $3 a$ ). With this receptor rANP(REA18) had a slightly reduced affinity with $\mathrm{IC}_{50}=438 \mathrm{pM}$. On average the binding was approximately two to fivefold reduced to NPR-A. The concentration response for cGMP stimulation on rNPR-A expressing cell lines showed both molecules to be essentially equipotent, with $\mathrm{ED}_{50}$ 's of 1.80 and $1.87 \mathrm{nM}$ for $\mathrm{rANP}$ and rANP(REA18), respectively (Fig. $3 b$ ).

Neutral endopeptidase assay. To determine if rANP(REA18) was significantly different than rANP in its sensitivity to NEP degradation we measured the kinetic parameters of NEP on these two substrates. Table I summarizes the results of three experiments on rANP(REA18) and two experiments on rANP. For rANP(REA18) there was four to fivefold lowering in the $K_{\mathrm{m}}$, however, this was balanced by a $6-11$-fold reduction in the turnover number, $\mathrm{k}_{\mathrm{cat}}$. The net result is that on average
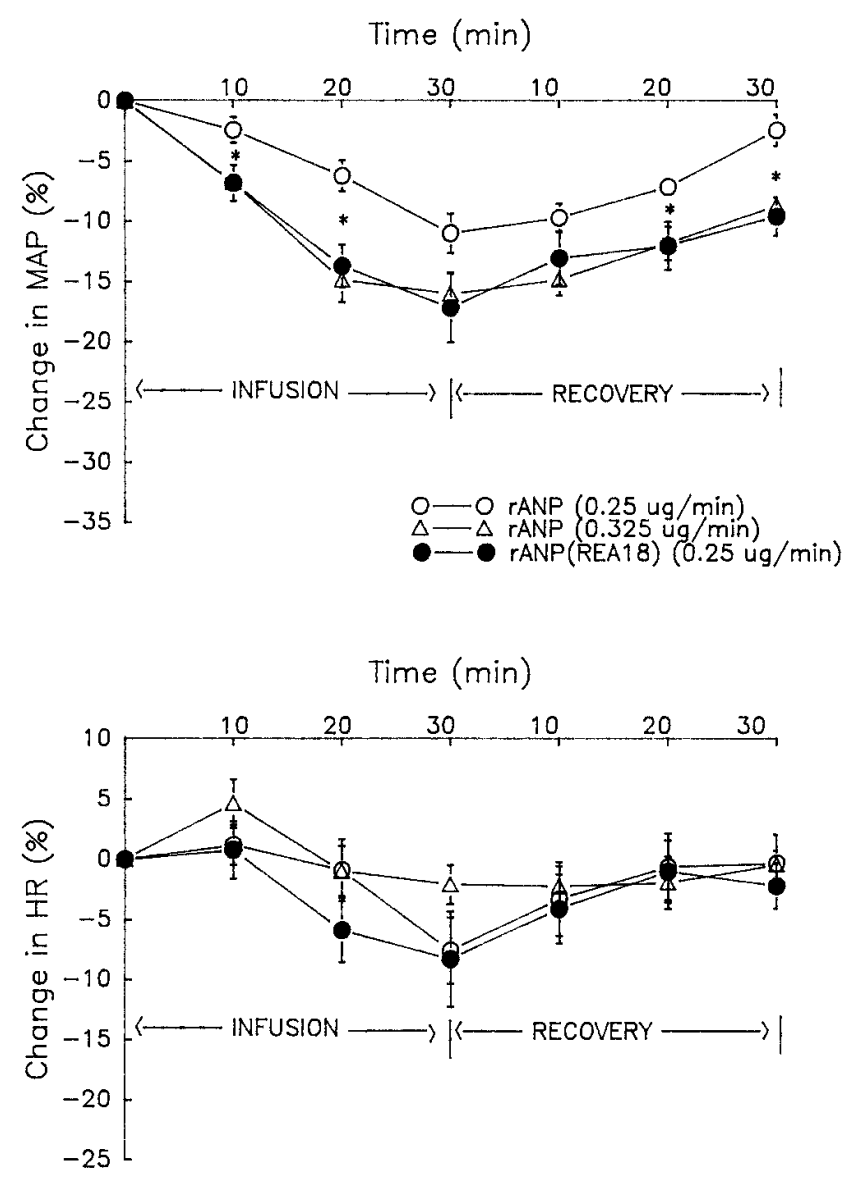

Figure 5. Monitoring the responses of MAP and HR to rANP and rANP(REA18) in conscious rats. $* P<0.05$, comparison between the rANP $(0.25 \mathrm{mg} / \mathrm{min})$ group and other two groups. Changes $(\%)$ are expressed as infusion or recovery value minus control value, divided by control value. Values are expressed as mean \pm SEM, $n=10$ for each group.

the catalytic efficiency $\left(\mathrm{k}_{\mathrm{cat}} / K_{\mathrm{m}}\right)$ of NEP for $\mathrm{rANP}(\mathrm{REA} 18)$ is decreased by $36 \%$ compared to rANP.

Aortic ring relaxation. The direct vasodilatory effects $\mathrm{rANP}$ and $\mathrm{rANP}(\mathrm{REA} 18)$ were compared in rat isolated aortic ring preparations to determine relative potency. Both native and

Table II. Basal Values of Parameters in Conscious Rats

\begin{tabular}{lccc}
\hline & rANP $(0.25 \mu \mathrm{g} / \mathrm{min})$ & rANP $(0.325 \mu \mathrm{g} / \mathrm{min})$ & $\begin{array}{c}\text { rANP(REA18) } \\
(n=10)\end{array}$ \\
\hline $\mathrm{BW}(\mathrm{grams})$ & $346 \pm 5.7$ & $336.4 \pm 4.3$ & $344.7 \pm 9.0$ \\
$\mathrm{MAP}(\mathrm{mmHg})$ & $122.5 \pm 3.4$ & $122.2 \pm 3.9$ & $128.1 \pm 3.5$ \\
$\mathrm{HR}(\mathrm{bpm})$ & $393 \pm 10$ & $384 \pm 9$ & $389 \pm 6$ \\
$\mathrm{UV}(\mu \mathrm{min})$ & $24.5 \pm 3.9$ & $34.1 \pm 9.9$ & $21.2 \pm 4.4$ \\
$\mathrm{U}_{\mathrm{Na}} \mathrm{V}(\mu \mathrm{mol} / \mathrm{min})$ & $0.53 \pm 0.25$ & $1.26 \pm 0.49$ & $0.52 \pm 0.25$ \\
$\left.\mathrm{U}_{\mathrm{cGMP}} \mathrm{Vmol} / \mathrm{min}\right)$ & $21.6 \pm 6.2$ & $26.6 \pm 9.1$ & $12.8 \pm 4.9$ \\
$\mathrm{PcGMP}(\mathrm{pmol} / \mathrm{min})$ & $5.9 \pm 0.7$ & $5.1 \pm 0.5$ & $6.7 \pm 1.5$ \\
& & & \\
\end{tabular}

Values are expressed as mean \pm SEM. BW, body weight; $\mathrm{UV}$, urine volume; $\mathrm{U}_{\mathrm{Na}} \mathrm{V}$, urinary sodium excretion; $\mathrm{U}_{\mathrm{cGMP}} \mathrm{V}$, urinary cGMP excretion; PcGMP, plasma cGMP levels. 

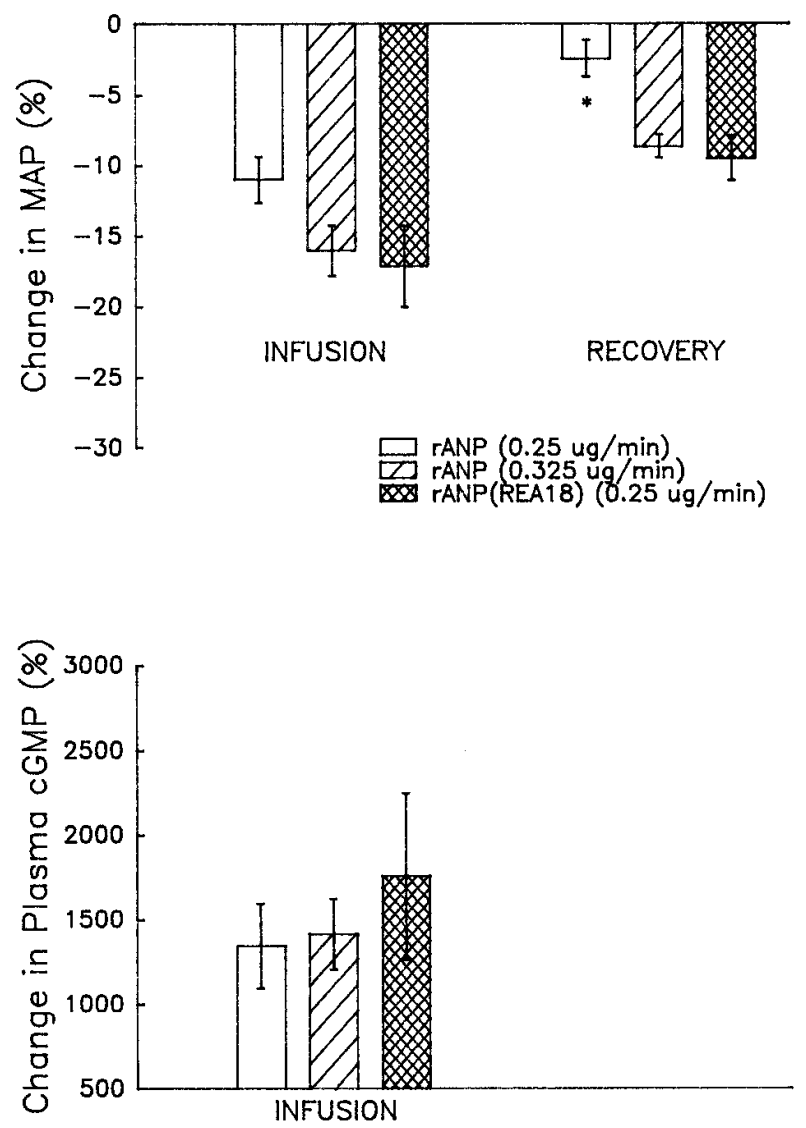

Figure 6. Effects of rANP or rANP(REA18) on MAP and plasma cGMP levels in conscious rats. ${ }^{*} P<0.05$, compared with the other two groups. Changes (\%) are expressed as infusion or recovery value minus control value, divided by control value. Values are expressed as mean $\pm \operatorname{SEM}(n=10)$.

mutant rANP were equipotent in relaxing phenylephrine-contracted aortic rings, with an $\mathrm{IC}_{50}$ of $1.3 \mathrm{nM}$ (Fig. 4).

Basal levels of parameters in conscious rats. Surgery was performed in 32 rats, 2 of which were excluded from the study due to bleeding. Body weight in the included 30 rats was $342.6 \pm 4.1$ grams. At the end of the control period, i.e., after $30 \mathrm{~min}$ of saline infusion and before infusion of natriuretic peptides, there were no significant differences in the basal levels of MAP, HR, urine volume, urine sodium, urine cGMP, and plasma cGMP between the experimental groups (Table II).

Effects of rANP or $r A N P(R E A 18)$ on MAP and HR. Intravenous infusion of rANP or $\mathrm{PANP}(\mathrm{REA} 18)$ significantly reduced MAP in conscious rats (Figs. 5 and 6, top). When both molecules were given at the same dose $(0.25 \mu \mathrm{g} / \mathrm{min}), \mathrm{rANP}(\mathrm{REA} 18)$ induced a significantly greater reduction in MAP than rANP at 10 and $20 \mathrm{~min}$ of the infusion period, and at 20 and $30 \mathrm{~min}$ of the recovery period $(P<0.05)$ (Fig. 5, top $)$. The difference in MAP was not statistically significant at the end $(30 \mathrm{~min})$ of the infusion period (Figs. 5 and 6, top). At the end of the 30-min recovery period MAP had returned to baseline for rANP-treated rats whereas there continued to be significant depression of MAP with $\mathrm{rANP}(\mathrm{REA} 18)$. $\mathrm{rANP}$ at $0.325 \mu \mathrm{g} / \mathrm{min}$ and $\mathrm{rANP}(\mathrm{REA} 18)$ at $0.25 \mu \mathrm{g} / \mathrm{min}$ had identical effects on MAP for both the infusion and recovery periods (Figs. 5 and 6, top). Neither rANP nor rANP(REA18) altered HR significantly (Fig. 5, bottom).
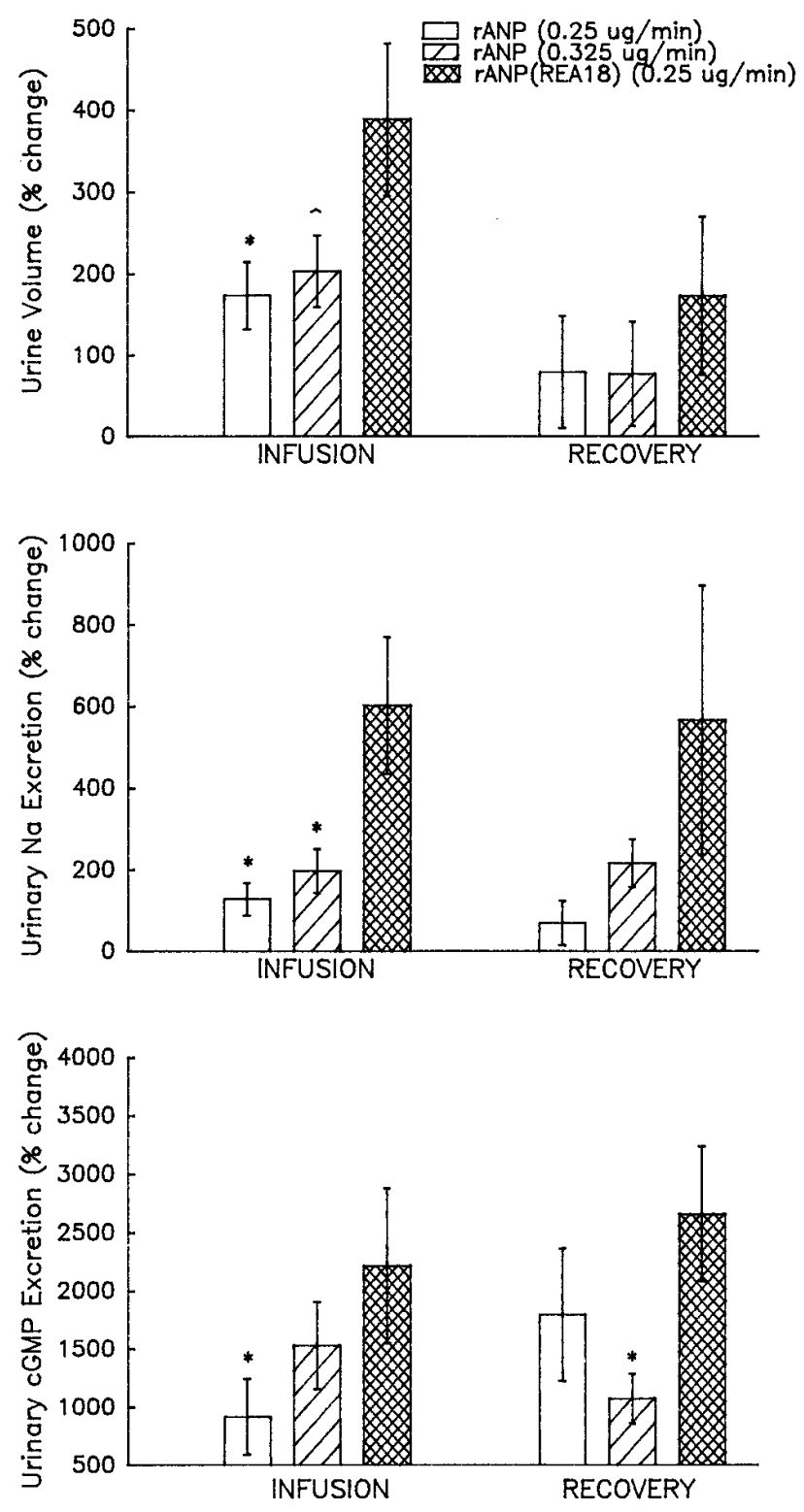

Figure 7. Effects of rANP and rANP(REA18) on urinary volume $(U V)$, urinary sodium excretion, and urine cGMP levels in conscious rats. ${ }^{\wedge} P<0.1, * P<0.05$, compared with the rANP(REA18) group. Changes (\%) are expressed as infusion or recovery value minus control value, divided by control value. Values are expressed as mean $\pm \operatorname{SEM}(n=10)$.

Urine volume and $\mathrm{Na}^{+}$excretion. Both natriuretic peptides increased urine volume and urinary $\mathrm{Na}^{+}$excretion (Fig. 7, top and middle). rANP(REA18) $(0.25 \mu \mathrm{g} / \mathrm{min})$ significantly enhanced the diuretic response compared to rANP at the same dose $(P<0.05)$, and tended to enhance diuresis compared with $\mathrm{rANP}$ at the higher dose $(0.325 \mu \mathrm{g} / \mathrm{min})(P=0.07)$ (Fig. 7 , top). The natriuretic response to $\mathrm{rANP}(\mathrm{REA} 18)$ was significantly greater than that to $\mathrm{rANP}$ at the same dose $(P<0.05)$ as well as at the higher dose $(P<0.05)$ (Fig. 7, middle).

$c G M P$ responses. rANP and $\mathrm{rANP}(\mathrm{REA} 18)$ markedly elevated plasma and urinary cGMP levels (Fig. 6 and 7, bottom). The elevation in the plasma level of cGMP in response to rANP(REA18) was enhanced compared to that to rANP at ei- 
ther dose, but the difference was not statistically significant (Fig. 4, bottom). The rANP(REA18)-induced increase in urinary cGMP levels was significantly augmented as compared to that induced by rANP at the same dose for the infusion period (Fig. 7, bottom). The response of urinary cGMP excretion to rANP(REA18) was enhanced as compared to rANP at the higher dose. The difference, however, was statistically significant only for the recovery period and not for the infusion period.

\section{Discussion}

In the present study, we describe the development and pharmacological properties of a novel ANP analog that has reduced binding to rNPR-C and retains full agonist potency on rNPR-A. The need to develop a molecule specific for the rat was based on the observation that the hNPR-A selective ANP variant had reduced potency on the rat receptor (16). This is perhaps not surprising since both NPR-A and NPR-C show marked species-specific differences in pharmacology for a variety of ANP analogs $(19,22)$. In the case of the human receptors, combination of ANP mutations G9T, R11S, and G16R abolished NPR-C binding while retaining full agonist potency on human NPR-A (16). Competitive selection of ANP display phage libraries with the rat receptors identified the ANP mutant G16R, A17E, Q18A as the dominant rat NPR-A selective variant, with 180-200-fold reduced binding of rANP(REA18) to rat NPR-C. In comparison to the selection with the human receptors, no receptor selective mutations were obtained in ANP positions 9, 10, or 11 . Thus in contrast to the selection with the human receptors, we identified only one region in rANP imparting reduced rNPR-C binding, and we did not have the option of combining mutations to abolish binding. The G16R mutation is common to the two experiments, but additional substitutions were also found at positions 17 and 18 when selected with the rat receptors. The specific role of each substitution in rANP(REA18) in reducing binding to rNPR-C remains to be determined.

Competition binding studies on the cloned rat receptors, combined with concentration-response stimulation of cGMP production, demonstrated that $\mathrm{rANP}(\mathrm{REA} 18)$ retained full agonist potency on rNPR-A compared with rANP. In relaxation experiments on precontracted rat aortic rings both molecules were indistinguishable. There is very close agreement between the potency of the two peptides in the stimulation of cGMP production with recombinant NPR-A $\left(\mathrm{ED}_{50}=1.8 \mathrm{nM}\right)$ and in the relaxation of precontracted aortic rings $\left(\mathrm{IC}_{50}=1.3\right.$ $\mathrm{nM}$ ), in agreement with the role of cGMP as a second messenger of endothelium-independent smooth muscle relaxation (6).

In contrast to the in vitro relaxation studies, rANP was less active than $\mathrm{rANP}(\mathrm{REA} 18)$ at eliciting a decrease in arterial pressure when infused into rats. The mechanisms for the depressor effect of ANP in intact animals are not entirely understood. In addition to the vasorelaxant effect of ANP, the fall in arterial pressure is, at least in part, due to a reduction in cardiac output resulting from a decrease in plasma volume (1). This decrease in plasma volume is ascribed to a shift of fluid from intra- to extravascular compartments (1). Inhibition of sympathetic outflow preventing a reflex adjustment to the diminished plasma volume may also be involved in the depressor response to ANP (28). Regardless of these mechanisms, the enhanced depressor effect of $\mathrm{AANP}(\mathrm{REA} 18)$ can be attributed to the reduced binding of $\mathrm{rANP}(\mathrm{REA} 18)$ to $\mathrm{rNPR}-\mathrm{C}$, which should lead to slower clearance and higher plasma concentrations compared to rANP. In vitro cell culture experiments and in vivo pharmacokinetic studies have described a role for NPR-C in ANP clearance and degradation. ANP bound to NPR-C is internalized at a rate faster than the hormonal offrate, and is subsequently degraded in a lysozomal compartment prior to receptor recycling to the cell surface (29). When NPR-C is blocked in vivo with truncated ANP analogs that do not bind NPR-A there is a decrease in the metabolic clearance rate and in the steady-state volume of distribution for ANP, and an increase in the half life $(17,18)$. It is estimated that there is a $99 \%$ reserve of unoccupied NPR-C under normal conditions (17), providing a receptor reserve capable of hormonal buffering (13) during acute changes in plasma ANP concentrations. The simplest explanation for the increased response to rANP(REA18) may be pharmacokinetic given the role of NPR-C in ANP clearance. This, however, remains to be directly tested.

In addition to clearance mediated by NPR-C, there is also a clearance role for neutral endopeptidase as an extracellular protease for degradation of ANP $(1,16)$. To address the possibility of differential sensitivity of rANP and rANP(REA18) to proteolysis we measured the kinetic parameters of NEP on these two substrates. rANP(REA18) was only $36 \%$ more resistant to degradation than rANP as measured by the catalytic efficiency $\left(\mathrm{k}_{\mathrm{cat}} / K_{\mathrm{m}}\right)$. It seems to be unlikely that the small reduction in NEP sensitivity significantly contributes to the enhanced renal effects of rANP(REA18). The magnitude of the reduced sensitivity to NEP, 36\%, compared to the 180-200-fold reduction in NPR-C affinity suggests that the relative differences between $\mathrm{rANP}$ and $\mathrm{rANP}(\mathrm{REA} 18)$ in their in vivo properties derive primarily from receptor selectivity.

The increased activity of $\mathrm{rANP}(\mathrm{REA} 18)$ in eliciting a depressor effect on MAP is also manifest in increased renal responses, including urinary volume, sodium, and cGMP excretion. These effects are likely due to a higher effective concentration of rANP(REA18) as a result of reduced clearance. To determine if coexpression of NPR-A and NPR-C in the kidney attenuates responsiveness, we compared the renal response to an infusion of $0.25 \mu \mathrm{g} / \mathrm{min} \mathrm{rANP}(\mathrm{REA} 18)$ to a higher dose of rANP $(0.325 \mu \mathrm{g} / \mathrm{min})$ that gave an equivalent decrease in MAP. We would expect the two molecules to have very similar plasma concentrations under these different doses. While the higher dose of rANP did result in an incremental but not significant increase in the renal response, rANP(REA18) at $0.25 \mu \mathrm{g} / \mathrm{min}$ still elicited a greater output of urine volume $(P=0.07)$ and urine sodium $(P<0.05)$.

The results of our experiments in conscious rats measuring vascular and renal responses demonstrate that rANP(REA18) is more active than rANP. When both molecules are administered at doses that produce equivalent depressor responses rANP(REA18) remains a more effective agonist of renal function. We interpret this observation to mean that decreased NPR-C binding leads to enhanced activity in eliciting a natriuretic and diuretic response. Cell culture experiments show that coexpression of NPR-A and NPR-C results in a shift in the ANP concentration response curve for cGMP production to higher values (16), suggesting that coexpression of these receptors in the glomerulus could have a similar effect. Another consideration is the potential role of NPR-C in reducing the concentration of ANP delivered to downstream sites in the re- 
nal circulation. Hence nephron and collecting duct epithelial cells may also be exposed to higher concentrations of rANP(REA18) by virtue of not being cleared by glomerular NPR-C.

Our data are consistent with a specific role for NPR-C as a decoy receptor acting in local attenuation of ANP targeting to NPR-A in the kidney, resulting in a selectively decreased renal response to acute changes in plasma ANP. While this is not exclusive of a role for NPR-C in hormonal clearance through a large receptor reserve $(12,17,18)$, one consequence will be that sites of receptor coexpression will exhibit relatively lower cGMP production from NPR-A due to a shift in the concentration response curve to higher ANP concentrations. NPR-A is expressed in the glomerulus and throughout the nephron, with highest levels in the glomerulus and innermedullary-collecting ducts (30-32). Despite the high levels of expression in the glomerulus, ANP stimulation of cGMP production is attenuated, with reports of reduced potency where $\mathrm{ED}_{50}=10-100$ $\mathrm{nM}$ (32) compared to $\mathrm{ED}_{50} \sim 1 \mathrm{nM}$ for stimulation of cGMP on the cloned receptor.

Evidence of an enhanced renal response in the context of NPR-C blockade is also suggested in the results of Maack et al. (13), who first described a role for NPR-C in hormonal clearance and buffering. When the NPR-C selective analog $\mathrm{cANF}_{4-23}$ was coinfused with ANP in the isolated, perfused, rat kidney, these investigators observed a trend toward both increased potency $\left(\mathrm{ED}_{50}\right)$ and an increased maximal response for urinary sodium excretion (13). An analogous experiment has been described in vivo for coinfusion into rats of hANP and the analog $\mathrm{hANP}(0-\mathrm{Met})$ with an oxidized methionine at position 12 (33). This analog is more selective for NPR-C than NPR-A $(19,22$, 33 ), and when coinfused with hANP there is a synergistic effect on diuresis (natriuresis was not measured) (33). For both of these experiments $(13,33)$ the selective blocking, or binding, of NPR-C by these ANP analogs resulted in an increased renal response during coinfusion with ANP, consistent with our proposed role for NPR-C as a decoy receptor attenuating renal NPR-A activation.

The decoy receptor hypothesis for renal NPR-C merits careful future investigation. A more direct test of this hypothesis will require detailed dose-response experiments on renal function and blood pressure effects. Measurement of pharmacokinetics and plasma levels of hormone will be required to ensure appropriate dosing comparisons. Furthermore, a potentially important test of this hypothesis will be in measurements of cGMP stimulation from isolated glomeruli.

Our data with rANP(REA18) suggest a model in which reduced NPR-C binding results in an enhanced renal effect by increasing the available hormone concentration at NPR-A in the glomerulus, along with delivery of more ANP to postglomerular sites by the renal circulation. The net result is both enhanced diuresis and natriuresis compared to the depressor effect. The degree of the improved renal response, that is the therapeutic index, could be clinically significant considering that the hypotensive effect of ANP is dose limiting for renal efficacy (34). Receptor selective ANP variants may have improved activity over ANP for the treatment of acute renal failure and acute heart failure.

\section{Acknowledgments}

The authors thank Martin Struble and Kathryn Chan for peptide purification, Dr. Robert Bridenbaugh and K. MacFadden for purified recombinant NEP, Alan Padua for amino acid analysis, the Genentech DNA synthesis lab for oligonucleotides, Allison Bruce for artwork, and Kathie Ward for preparation of the manuscript.

\section{References}

1. Brenner, B.M., B.J. Ballermann, M.E. Gunning, and M.L. Zeidel. 1990. Diverse biological actions of atrial natriuretic peptide. Physiol. Rev. 70:665699.

2. John, S.W.M., J.H. Krege, P.M. Oliver, J.R. Hagaman, J.B. Hodgin, S.C. Pang, T.G. Flynn, and O. Smithies. 1995. Genetic decreases in atrial natriuretic peptide and salt-sensitive hypertension. Science (Wash. DC). 267:679-681.

3. Steinhelper, M.E., K.L. Cochrane, and L.J. Field. 1990. Hypotension in transgenic mice expressing atrial natriuretic factor fusion genes. Hypertension (Dallas). 16:301-307.

4. Ruskoaho, H. 1993. Atrial natriuretic peptide: synthesis, release, and metabolism. Pharmacol. Rev. 44:479-602.

5. Wilkins, M.R., S.L. Settle, and P. Needleman. 1990. Augmentation of the natriuretic activity of exogenous and endogenous atriopeptin in rats by inhibition of guanosine $3^{\prime}, 5^{\prime}$-cyclic monophosphate degradation. J. Clin. Invest. 85: 1274-1279.

6. Murad, F. 1986. Cyclic guanosine monophosphate as a mediator of vasodilation. J. Clin. Invest. 78:1-5.

7. Chinkers, M., D.L. Garbers, M.-S. Chang, D.G. Lowe, H. Chin, D.V. Goeddel, and S. Schulz. 1989. A membrane form of guanylate cyclase is an atrial natriuretic peptide receptor. Nature (Lond.). 338:78-83.

8. Lowe, D.G., M.S. Chang, R. Hellmiss, E. Chen, S. Singh, D.L. Garbers, and D.V. Goeddel. 1989. Human atrial natriuretic peptide receptor defines a new paradigm for second messenger signal transduction. Eur. Mol. Biol. Org. J. 8:1377-1384.

9. Wilcox, J.N., A. Augustine, D.V. Goeddel, and D.G. Lowe. 1991. Differential regional expression of three natriuretic peptide receptor genes within primate tissues. Mol. Cell. Biol. 11:3454-3462.

10. Sarzani, R., V.M. Paci, P. Dessì-Fulgheri, E. Espinosa, and A. Rappelli. 1993. Comparative analysis of atrial natriuretic peptide receptor expression in rat tissues. J. Hypertens. 11:S214-S215.

11. Porter, J.G., A. Arfsten, F. Fuller, J.A. Miller, L.C. Gregory, and J.A. Lewicki. 1990. Isolation and functional expression of the human atrial natriuretic peptide clearance receptor cDNA. Biochem. Biophys. Res. Commun. 171:796-803.

12. Maack, T. 1992. Receptors of atrial natriuretic factor. Annu. Rev. Physiol. 54:11-27.

13. Maack, T., M. Suzuki, F.A. Almeida, D. Nussenzveig, R.M. Scarborough, J.A. McEnroe, and J.A. Lewicki. 1987. Physiological role of silent receptors of atrial natriuretic factor. Science (Wash. DC). 238:675-678.

14. Anand-Srivastava, M.B., and G.J. Trachte. 1993. Atrial natriuretic factor receptors and signal transduction mechanisms. Pharmacol. Rev. 45:455-497.

15. Rutherford, R.A.D., J. Wharton, P. Needleman, and J.M. Polak. 1991. Autoradiographic discrimination of brain and atrial natriuretic peptide-binding sites in the rat kidney. J. Biol. Chem. 266:5819-5826.

16. Cunningham, B.C., D.G. Lowe, B. Li, B.D. Bennett, and J.A. Wells. 1994. Production of an atrial natriuretic peptide variant that is specific for type A receptors. Eur. Mol. Biol. Org. J. 13:2508-2515.

17. Almeida, F.A., M. Suzuki, R.M. Scarborough, J.A. Lewicki, and T. Maack. 1989. Clearance function of type $\mathrm{C}$ receptors of atrial natriuretic factor in rats. Am. J. Physiol. 256:R469-R475.

18. Okolicany, J., G.A. McEnroe, G.Y. Koh, J.A. Lewicki, and T. Maack 1992. Clearance receptor and neutral endopeptidase-mediated metabolism of atrial natriuretic factor. Am J. Physiol. 263:F546-F553.

19. Engel, A., J.R. Schoenfeld, and D.G. Lowe. 1994. A single residue determines the distinct pharmacology of rat and human natriuretic peptide receptor-C. J. Biol. Chem. 269:17005-17008.

20. Bennett, B.D., G.L. Bennett, R.V. Vitangcol, J.R.S. Jewett, J. Burnier, W. Henzel, and D.G. Lowe. 1991. Extracellular domain-IgG fusion proteins for three human natriuretic peptide receptors. J. Biol. Chem. 266:23060-23067.

21. Li, B., J.Y.K. Tom, D. Oare, R. Yen, W. Fairbrother, J.A. Wells, and B.C. Cunningham. 1995. Minimization of a polypeptide hormone. Science (Wash. DC). 270:1657-1660.

22. Schoenfeld, J.R., P. Sehl, C. Quan, J.P. Burnier, and D.G. Lowe. 1995. Agonist selectivity for three species of natriuretic peptide receptor-A. Mol. Pharmacol. 47:172-180.

23. Kenny, A.J., A. Bourne, and J. Ingram. 1993. Hydrolysis of human and pig brain natriuretic peptides, urodilatin, C-type natriuretic peptide and some C-receptor ligands by endopeptidase-24.11. Biochem. J. 291:83-88.

24. Koller, K.J., D.G. Lowe, G.L. Bennett, N. Minamino, K. Kangawa, H. Matsuo, and D.V. Goeddel. 1991. Selective activation of the B natriuretic peptide receptor by C-type natriuretic peptide (CNP). Science (Wash. DC). 252: $120-123$.

25. Munson, P.J., and D. Rodbard. 1980. Ligand: a versatile computerized approach for characterization of ligand-binding systems. Anal. Biochem. 107: 
$220-239$

26. Furchgott, R., and J. Zawadzki. 1980. The obligatory role of endothelial cells in the relaxation of arterial smooth muscle by acetylcholine. Nature (Lond.). 288:373-376.

27. Jin, H., C. Mathews, Y.-F. Chen, R. Yang, J.M. Wyss, P. Esunge, and S. Oparil. 1992. Effects of acute and chronic blockade of neutral endopeptidase with Sch 34826 on NaCl-sensitive hypertension in spontaneously hypertensive rats. Am. J. Hypertens. 5:210-218.

28. Schultz, H.D., M.K. Steele, and D.G. Gardner. 1990. Central administration of atrial natriuretic peptide decreases sympathetic outflow in rats. Am. J. Physiol. 258:R1250-R1256.

29. Nussenzveig, D.R., J.A. Lewicki, and T. Maack. 1990. Cellular mechanisms of the clearance function of type $\mathrm{C}$ receptors of atrial natriuretic factor. $J$. Biol. Chem. 265:20952-20958.

30. Terada, Y., T. Moriyama, B.M. Martin, M.A. Knepper, and A. GarciaPerez. 1991. RT-PCR microlocalization of mRNA for guanylyl cyclase-coupled ANF receptor in rat kidney. Am. J. Physiol. 261:F1080-F1087.
31. Nonoguchi, H., M.A. Knepper, and V.C. Manganiello. 1987. Effects of atrial natriuretic factor on cyclic guanosine monophosphate and cyclic adenosine monophosphate accumulation in microdissected nephron segments from rats. J. Clin. Invest. 79:500-507.

32. Chabardes, D., M. Montegut, M. Mistaoui, D. Butler, and F. Morel. 1987. Atrial natriuretic peptide effects on cGMP and cAMP contents in microdissected glomeruli and segments of the rat and rabbit nephrons. Pflugers Arch. 408:366-372.

33. Koyama, S., T. Terai, T. Inoue, K. Inomata, K. Tamura, Y. Kobayashi, Y. Kyogoku, and M. Kobayashi. 1992. An oxidized analog of a-human atrial natriuretic polypeptide is a selective agonist for the atrial-natriuretic-polypeptide clearance receptor which lacks a guanylate cyclase. Eur. J. Biochem. 203: $425-432$.

34. Blaine, E.H., L.A. Heinel, T.W. Schorn, E.A. Marsh, and M.A. Whinnery. 1986. The character of the atrial natriuretic response: pressure and volume effects. J. Hyperten. 4:S17-S24. 